\title{
Development of Calcium Channels in Gastric Smooth Muscle
}

\author{
P. E. HYMAN, M. G. MARTIN, T. TOMOMASA, J. JING, W. J. SNAPE, JR. \\ Departments of Pediatrics and Medicine, and the Inflammatory Bowel Disease Center, Harbor-UCLA Medical \\ Center, Torrance, California 90509
}

\begin{abstract}
We used $\left[{ }^{3} \mathrm{H}\right]$ nitrendipine to characterize dihydropyridine sensitive calcium channels on cells isolated from neonatal (1 d) and weanling (11 wk) rabbit gastric fundic and antral smooth muscle. Incubating with and without nifedipine $20 \mu \mathrm{M}$, specific binding was $56 \pm 4 \%$ of total binding at $0.1 \mathrm{nM}\left[{ }^{3} \mathrm{H}\right]$ nitrendipine. Specific binding was saturable, reversible, achieved equilibrium by $10 \mathrm{~min}$ at $4^{\circ} \mathrm{C}$, and was linearly related to cell concentration. The affinity constant for $\left[{ }^{3} \mathrm{H} \mid\right.$ nitrendipine was higher in weanling fundus $\left(k_{d}=243 \pm 121 \mathrm{pM}\right)$ versus antrum $\left(k_{d}=771\right.$ $\pm 190 \mathrm{pM}), p<0.05$. There were no age-related changes in affinity. In the antrum, the number of binding sites $\left(B_{\max }\right)$ increased from $6000 \pm 266 /$ cell in neonates to 27 $500 \pm 8440 /$ cell in weanlings $(p<0.05)$. In the fundus $B_{\max }$ was $7750 \pm 2100 /$ cell in neonates, and there was no age-related change. To assess function, we compared isometric stress in full thickness muscle strips oriented to the circular layer. Bethanechol stimulated dose-dependent tonic contractions in the fundus and phasic contractions in the antrum. Maximal stress increased with age from 305 $\pm 54 \mathrm{mN} / \mathrm{cm}^{2}$ to $1140 \pm 73 \mathrm{mN} / \mathrm{cm}^{2}(p<0.05)$ in the fundus and from $72 \pm 20 \mathrm{mN} / \mathrm{cm}^{2}$ to $154 \pm 30 \mathrm{mN} / \mathrm{cm}^{2}(p$ $<0.05)$ in the antrum. Preincubation and incubation without calcium resulted in reversible inhibition of contraction at both ages. Nifedipine $10-\mu \mathrm{M}$ inhibited $100 \%$ of bethanechol-stimulated contraction in the antrum, but only $25 \%$ in the fundus at both ages. In summary, in rabbit gastric smooth muscle: 1) $\left[{ }^{3} \mathrm{H}\right]$ nitrendipine identified functional calcium channels in neonates and weanlings, 2) there are age-related increases in calcium channels on antral, but not on fundic cells, 3 ) there are age-related increases in stress in strips from antrum and fundus, 4) the fundus utilizes intracellular calcium stores for bethanechol-stimulated contraction, whereas the antrum requires extracellular calcium. Age-related increases in dihydropyridine sensitive calcium channels are consistent with the requirement of the antrum for extracellular calcium to support contraction. (Pediatr Res 25:600-604, 1989)
\end{abstract}

In muscle strips from rabbit stomach, maximal contraction was greater in adult compared to newborn animals (1). These data were compatible with studies in humans, showing that the intraluminal pressures achieved in the stomach are greater in adults compared to neonates (2). The age-related changes in gastric smooth muscle physiology that are responsible for increasing contraction have not been examined.

Received July 20, 1988; accepted February 14, 1989

Correspondence Paul E. Hyman, M.D. Harbor-UCLA Medical Center, 1000 West Carson Street, Torrance, CA 90509

Supported in part by NIH Grants HD-22912 and OK-31147 and the Inflammatory Bowel Disease Center Grant P30-AM-32200.
The mechanisms and controls for smooth muscle contraction are complex, and there are many factors that may contribute to the increasing contraction that is observed during postnatal development. One area of interest is the control of intracellular calcium concentration. An increase in intracellular calcium is required for the initiation of smooth muscle contraction (3). The sources of calcium mediating the increase may be the extracellular space or intracellular organelles. For example, in the cat, muscle from the esophageal body required calcium from the extracellular space, but the lower esophageal sphincter used calcium released from the endoplasmic reticulum (4).

As in the esophagus and lower esophageal sphincter, there are no distinct anatomic features separating the proximal and distal portions of the stomach, but there are striking differences in their motor functions (5). The proximal stomach (fundus and body) stores the gastric contents and exhibits slow, receptive relaxation and tonic contractions. The distal stomach (antrum) grinds the gastric contents during well-coordinated phasic contractions. Preliminary results in the cat indicated that these two portions of the stomach utilized different sources of calcium to support contraction (6).

Calcium influx from the extracellular space is achieved by movement through distinct calcium channels in the plasma membrane. These channels can be quantitated with radioligand binding, because dihydropyridine binding sites copurify with membrane-bound calcium channels (7).

The present studies were designed I) to quantitate dihydropyridine-sensitive calcium channels in rabbit gastric fundus and antrum, 2) to assess the sources of calcium required for contraction in these tissues, and 3) to determine if there were age-related changes in calcium channels that would help to explain the agedependent increases in maximal contraction.

\section{MATERIALS AND METHODS}

Male New Zealand white rabbits, both neonatal ( $1 \mathrm{~d}$ old $)$ and weanling (11 wk old), were obtained from ABC Rabbitry, Pomona, CA. HEPES was from Research Organics, Cleveland, $\mathrm{OH}$. Glutamine (tissue calcium grade) and BSA were from Sigma Chemical Co., St. Louis, MO. Basal Eagle's medium amino acids (100 times concentrated) were from Grand Island Biological Co. Grand Island, NY. Soybean trypsin inhibitor was from Cooper Biomedical, Inc., Malvern, PA. Collagenease $(179 \mathrm{U} / \mathrm{mg})$ was from Boehringer Mannheim, Indianapolis, IN. Tritiated nitrendipine $(73.7 \mathrm{Ci} / \mathrm{mmol})$ came from New England Nuclear, Boston, MA. Unlabeled nifedipine was from Pfizer Laboratories, New York, NY, and bethanechol chloride from Merck, Sharp and Dohme, West Point, PA.

Preparation of dispersed cells. The standard buffer contained (in mM): $\mathrm{NaCl} 115, \mathrm{KCl} 5.8, \mathrm{MgCl}_{2} 0.6, \mathrm{CaCl}_{2} 1.1, \mathrm{KH}_{2} \mathrm{PO}_{4} 2.1$, HEPES 25.0, glutamine 2.0, glucose $4.15 \mathrm{~g} / \mathrm{liter}$, and basal Eagle's medium amino acids $2.6 \%$ (vol/vol). The $\mathrm{pH}$ of the 
solution was adjusted to $\mathrm{pH} 7.4$ wit $\mathrm{NaOH}$. The osmolarity was 286 mosmol. For high potassium experiments, $\mathrm{KCl}$ was exchanged for $\mathrm{NaCl}$ to maintain osmolarity. All solutions were gassed with $100 \% \mathrm{O}_{2}$.

Smooth muscle cells were isolated from the gastric antrum and fundus of the rabbit by a technique similar to that introduced by Bitar and Makhlouf (8) and modified by Collins (9). After a weanling rabbit was killed, a $4 \times 2-\mathrm{cm}$ strip of stomach tissue was removed, washed in cold $\left(4^{\circ} \mathrm{C}\right)$ buffer, and pinned to the bottom of a dissecting tray filled with cold buffer with $100 \% \mathrm{O}_{2}$ bubbled through the solution. Using a dissecting microscope the mesentery was trimmed, the segment was turned mucosal side up, and the mucosa was removed by peeling it away from the muscularis with fine forceps. Confirmation of isolation of smooth muscle by this technique was obtained by examination of hematoxylin-eosin stained cross-sections of the muscle tissue preparation.

The tissue was minced with fine scissors and suspended in 15 $\mathrm{mL}$ of buffer with BSA $0.1 \%$ (wt/vol), collagenase $0.1 \%$ (wt/ $\mathrm{vol}$ ), and soybean trypsin inhibitor $0.01 \%$ (wt/vol). The tissue was incubated twice at $30^{\circ} \mathrm{C}$ for $55 \mathrm{~min}$ in a Dubnoff metabolic shaking incubator at $60 \mathrm{cycles} / \mathrm{min}$. After the second incubation, the tissue was washed twice with $40 \mathrm{~mL}$ of buffer, resuspended in $10 \mathrm{~mL}$ of buffer without collagenase and incubated for 20 min. After the third incubation, tissues were passed gently through a siliconized glass pipette with a $3-\mathrm{mm}$ orifice, and the dispersed cells were collected after passage through Nitex filter (500- $\mu \mathrm{m}$ pore size). The filtrate of dispersed cells was gassed with $100 \% \mathrm{O}_{2}$ and allowed to equilibrate to room temperature before use.

Adequate numbers of isolated myocytes from neonatal fundus and antrum were obtained by killing five animals for each experiment. Incubation techniques were similar to that used for weanling preparations.

The concentration of cells in the final filtrate was measured using phase-contrast hemocytometer and ranged between $2-6 \times$ $10^{6}$ cells $/ \mathrm{mL}$. A $4-\mathrm{cm}$ piece of antral or fundic smooth muscle isolated from a single weanling yielded approximately $10^{5}$ to $10^{6}$ cells. Cell viability, assessed by the ability of the cells to exclude $0.1 \%$ trypan blue, ranged from $80 \%$ to $95 \%$. The cells remained viable for at least $2 \mathrm{~h}$, and all experiments were performed within $1 \mathrm{~h}$ of completing the preparation of isolated cells.

Binding of ${ }^{3} \mathrm{H}$ Jnitrendipine. Aliquots of cell suspension containing 150000 to 400000 cells were added to silicon-coated test tubes containing various concentrations of $\left[{ }^{3} \mathrm{H}\right]$ nitrendipine and either $200-\mu \mathrm{M}$ unlabeled nifedipine or an equivalent amount of buffer to a final vol of $1.0 \mathrm{~mL}$. After incubation at $4^{\circ} \mathrm{C}$ for 45 min the contents of the tube were poured on to BSA-washed Whatman GF-A glass filters and the supernatant removed by vacuum extraction using a Millipore model 1225 vacuum filter apparatus. Unbound $\left[{ }^{3} \mathrm{H}\right]$ nitrendipine was washed through the filter with $10 \mathrm{~mL}$ washes with $0.9 \% \mathrm{NaCl}$ at $4^{\circ} \mathrm{C}$. The filters were placed into scintillation vials and $10 \mathrm{~mL}$ of budget-solve counting fluid was added to each vial. Measurements of radioactive decay were made with a Beckman LS 7800 Liquid Scintillation Counter (efficiency $40 \%$ ). Specific binding ranged from 20 to $60 \%$ of total binding. At concentrations of $400 \mathrm{pM}\left[{ }^{3} \mathrm{H}\right]$ nitrendipine or higher, more than $95 \%$ of the nonspecific binding was due to counts trapped on the filters.

Isometric tension. Full thickness muscle was obtained from neonates and weanling rabbits as described above. The muscle segments were cut into $10.0-\times 2.0$ - to 2.5 -mm strips along the circular axis with fine scissors. The strips were placed in a muscle bath holding $1.0 \mathrm{~mL}$ of oxygenated Krebs' solution and studied as previously described (10). One end of the muscle was attached via an inelastic wire to an isometric force transducer (Grass model FT-03C, Grass Instrument Co., Quincy, MA). The muscle was bathed in Krebs-Ringer solution with the composition (in $\mathrm{mM}$ ): $\mathrm{NaCl} 115, \mathrm{KCl} 4.6, \mathrm{MgCl}_{2} 2.1, \mathrm{NaH}_{2} \mathrm{PO}_{4} 1.2, \mathrm{NaHCO}_{3}$ $21.1, \mathrm{CaCl}_{2} 2.5$ and glucose 15.5 . The temperature was main- tained at $37^{\circ} \mathrm{C}$ and the bath was bubbled continuously with $95 \%$ $\mathrm{O}_{2}$ and $5 \% \mathrm{CO}_{2}$.

The muscle tissue was allowed to stabilize in the bath for $1 \mathrm{~h}$ and then was stretched by increments of $1 \mathrm{~mm}$ until muscle tension was ready to increase with any further increase in muscle length $\left(\mathrm{L}_{\mathrm{i}}\right)$. From this initial length, the muscle strip was progressively stretched by $0.5-$ to $1.0-\mathrm{mm}$ increments. After stretching, the muscle was contracted maximally using $10-\mu \mathrm{M}$ bethanechol. The bethanechol-stimulated active muscle tension was measured from the stable level of resting tension to the peak tension recorded after bethanechol administration. The optimum length of the muscle $\left(\mathrm{L}_{\mathrm{o}}\right)$ was the muscle length at which peak active tension developed. $\mathrm{L}_{\mathrm{o}}$ was determined for each strip. Contraction was expressed as stress per cross-sectional area (10). Bethanechol and nifedipine were diluted in Krebs-Ringer solution and added to the bath to provide the desired concentrations. Agonists and antagonists were added simultaneously to the bath. To increase extracellular potassium concentration, we drained all buffer solution from the bath. We immediately refilled the bath with a high potassium solution (10-120 mM) which was kept isotonic by replacing $\mathrm{NaCl}$ with $\mathrm{KCl}$. To study the effect of extracellular $\mathrm{Ca}^{2+}$, buffer composition was changed by omitting $\mathrm{CaCl}_{2}$ and adding $5 \mathrm{mM}$ EGTA.

After each drug administration, the muscle was washed free of the preceding test solution by replacing the chamber buffer twice with warm, well-oxygenated buffer. The chamber was refilled a third time, and the tension allowed to return to its previous resting level.

Data analysis. $\mathrm{K}_{\mathrm{d}}$ and the total number of receptors $\left(\mathrm{B}_{\max }\right)$ were determined from the results obtained from each separate experiment by using a nonlinear least-squares computer program (EBDA) (11). Unpaired $t$ tests were used to determine differences between experimental groups. $t$ tests with probabilities adjusted for multiple comparisons using Bonferroni criteria were used to compare age groups. All results are expressed as mean \pm SEM.

\section{RESULTS}

Kinetics of ${ }^{3}$ HJnitrendipine binding. As demonstrated in Figure 1 , specific binding was rapid, and achieved equilibrium by $10 \mathrm{~min}$ in antral weanling smooth muscle cells. Binding remained constant for at least $60 \mathrm{~min}$ at $4^{\circ} \mathrm{C}$. The time required for half of the bound radioligand to bind $\left(\mathrm{t}_{1 / 2}\right)$ was $2.5 \mathrm{~min}$. After $10 \mathrm{~min}$ of preincubation, the reversibility of $\left[{ }^{3} \mathrm{H}\right]$ nitrendipine was demonstrated by the addition of nifedipine $200 \mu \mathrm{M}$ (Fig. 1). The time

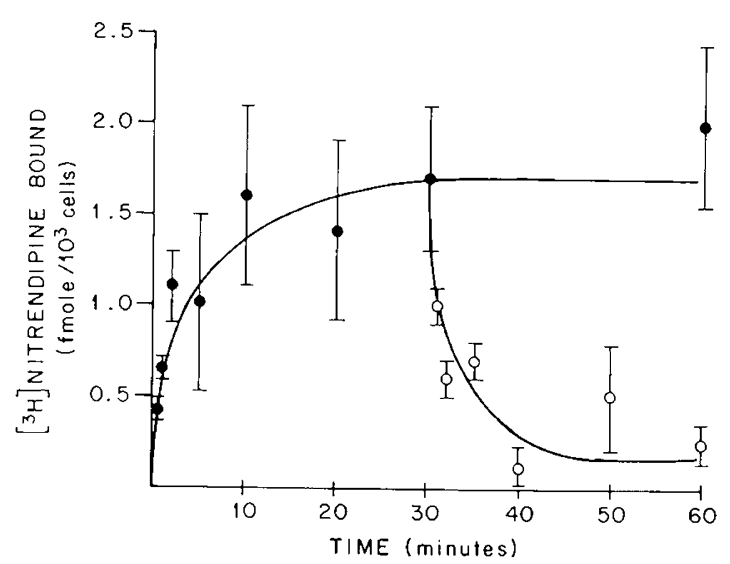

Fig. 1. Time course of $\left[{ }^{3} \mathrm{H}\right]$ nitrendipine association and dissociation. Cells from circular smooth muscle of the weanling antrum were incubated with $250 \mathrm{pM}\left[{ }^{3} \mathrm{H}\right]$ nitrendipine with or without $200 \mu \mathrm{M}$ unlabeled nifedipine at $4^{\circ} \mathrm{C}$ (closed circles). Dissociation was measured after adding unlabeled nifedipine to a final concentration of $200 \mu \mathrm{M}$ after $30 \mathrm{~min}$ of incubation with $\left[{ }^{3} \mathrm{H}\right]$ nitrendipine (open circles). Results are mean \pm SEM of five experiments. 
required for half of the bound radioligand to dissociate was 1 min. There were no age or tissue-related differences in the time courses for association or disassociation.

Effect of tissue concentration on $\left.{ }^{3} H\right]$ nitrendipine binding. In the antrum of the weanling $\left[{ }^{3} \mathrm{H}\right]$ nitrendipine binding was linearly related to cell concentration within the range tested (Fig. 2).

Concentration dependence of ${ }^{3} \mathrm{H} / n i t r e n d i p i n e ~ b i n d i n g . ~ S p e c i f i c$ binding of $\left[{ }^{3} \mathrm{H}\right]$ nitrendipine to adult antral myocytes was concentration dependent to $400 \mathrm{pM}$, but was saturated above this value (Fig. 3). Nonspecific binding was not saturable and in-

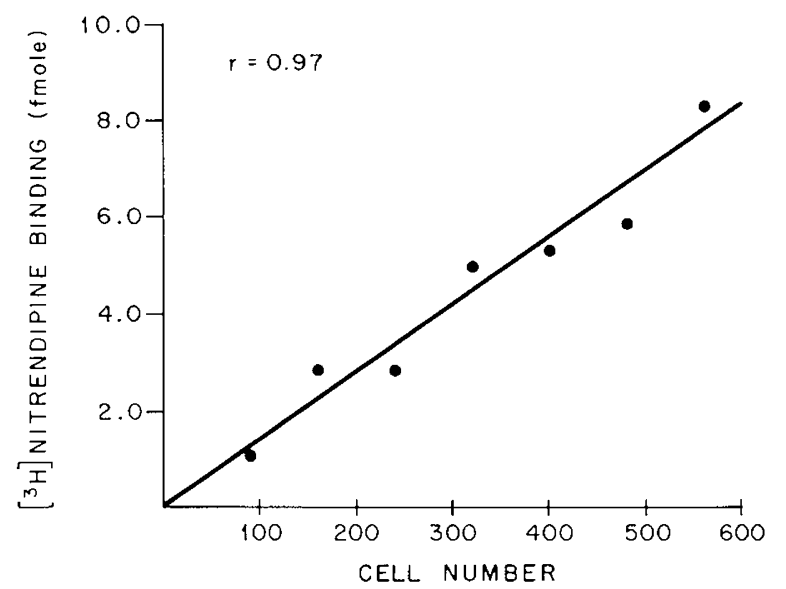

Fig. 2. Effect of tissue concentration on $\left[{ }^{3} \mathrm{H}\right]$ nitrendipine binding. Myocytes isolated from weanling antrum were incubated with $250 \mathrm{pM}$ $\left[{ }^{3} \mathrm{H}\right]$ nitrendipine with and without $200 \mu \mathrm{M}$ unlabeled nifedipine at $25^{\circ}$ $\mathrm{C}$ for $30 \mathrm{~min}$. Results are the means of triplicate determinations from a single study, and are representative of four other experiments.

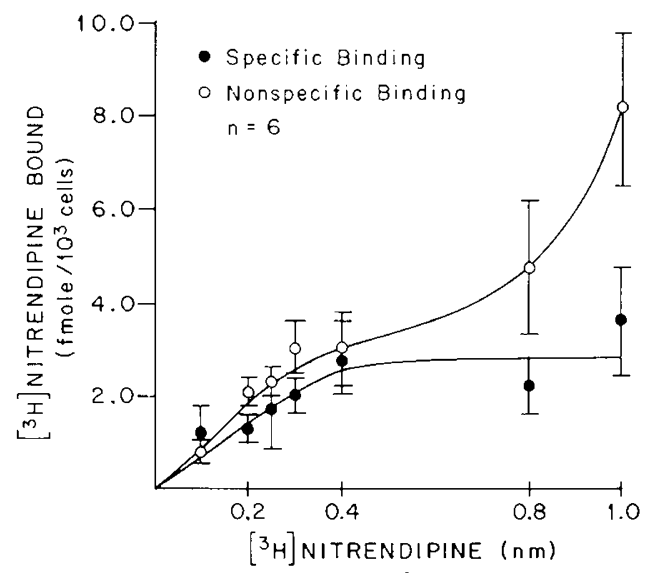

Fig. 3. Concentration dependence of $\left[{ }^{3} \mathrm{H}\right]$ nitrendipine binding to antral myocytes. Myocytes from weanling antrum were incubated with various concentrations of $\left[{ }^{3} \mathrm{H}\right]$ nitrendipine for $30 \mathrm{~min}$ at $25^{\circ} \mathrm{C}$ with and without $200 \mu \mathrm{M}$ unlabeled nifedipine. Specific binding (closed circles) is obtained by subtracting nonspecific binding (open circles) from total binding. Results are mean \pm SEM from six separate experiments. creased with $\left[{ }^{3} \mathrm{H}\right]$ nitrendipine concentration. Incubating with and without excess nifedipine $(20 \mu \mathrm{M})$, specific binding was 57 $\pm 4 \%$ of the total binding at $0.1 \mathrm{nM}\left[{ }^{3} \mathrm{H}\right]$ nitrendipine. Specific binding was saturable in adult fundus and neonatal tissues as well.

Table 1 summarizes the affinity and number of binding sites for nitrendipine on fundic and antral myocytes. The $K_{d}$ was greater for weanling fundus $(243 \pm 121 \mathrm{pM})$ than for weanling antrum $(771 \pm 190 \mathrm{pM}), p<0.02)$. There were no age-related changes. In the antrum, the number of binding sites $\left(\mathrm{B}_{\max }\right)$ increased from $6000 \pm 266 /$ cell in newborns to $27,500 \pm 8440$ in weanlings, $(p<0.05)$. In the fundus, there were $7700 \pm 2100$ binding sites/cell in newborns and $8700 \pm 1500$ in weanlings, $(p$ $>0.10)$. In the weanling rabbit there were more sites on antral compared to fundic myocytes $(p<0.05)$.

Isometric tension studies. Bethanechol-stimulated dose-dependent tonic contraction in the fundus, and phasic contractions in the antrum. As shown in Figure 4, there was an age-dependent 3 -fold increase in maximal stress in the fundus, from $305 \pm 54$ $\mathrm{mN} / \mathrm{cm}^{2}$ in neonates to $1140 \pm 73 \mathrm{mN} / \mathrm{cm}^{2}$ in weanlings, $p<$ 0.05 . There was a similar age-related 2 -fold increase from $72 \pm$ $20 \mathrm{mN} / \mathrm{cm}^{2}$ to $154 \pm 30 \mathrm{mN} / \mathrm{cm}^{2},(p<0.05)$ in the antrum.

To assess the effect of receptor-independent membrane depolarization on contraction, we determined the effect of increased extracellular $\mathrm{K}^{+}$concentration on stress. Depolarization of the plasma membrane allows entry of calcium from the extracellular space into the cell. In both fundus and antrum, $80-\mathrm{mM} \mathrm{K}^{+}$ stimulated the maximal response, with further increases in extracellular $\mathrm{K}^{+}$concentration resulting in no further increases in stress. In four separate experiments the maximal response in the fundus was $297 \pm 67 \mathrm{mN} / \mathrm{cm}^{2}$ in the neonate and $725 \pm 105$ $\mathrm{mN} / \mathrm{cm}^{2}$ in the weanling. In the antrum the maximal response was $35 \pm 9 \mathrm{mN} / \mathrm{cm}^{2}$ in the neonate and $81 \pm 32 \mathrm{mN} / \mathrm{cm}^{2}$ in the weanling.

When strips of smooth muscle were pre-incubated for $3 \mathrm{~min}$
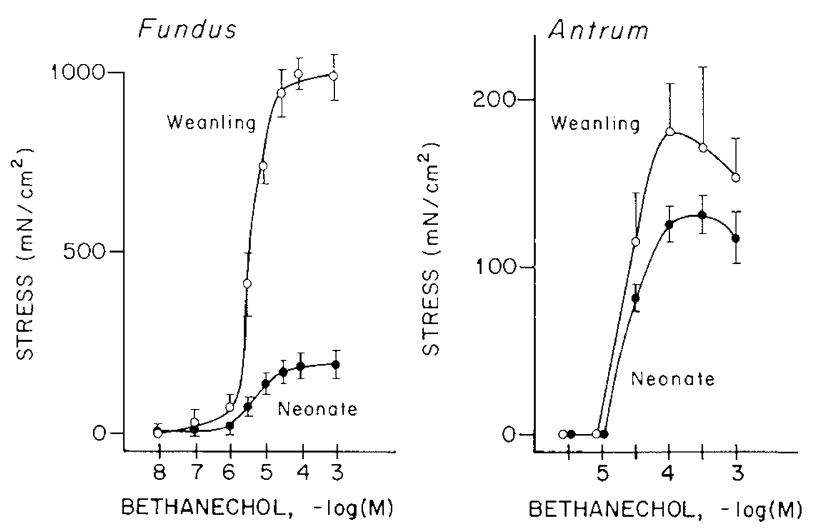

Fig. 4. Effect of age on bethanechol-stimulated contraction. Data represent mean \pm SEM of five separate experiments.

Table 1. Age-related changes in $\left.{ }^{3} H\right]$ nitrendipine binding sites $\left(B_{\max }\right)$ and affinity $\left(k_{d}\right) ; B_{\max }$ and $k_{d}$ were determined by nonlinear regression analysis for six separate experiments (results are mean $\pm S E M$ )

\begin{tabular}{|c|c|c|c|c|}
\hline & \multicolumn{2}{|c|}{ Antrum } & \multicolumn{2}{|c|}{ Fundus } \\
\hline & Neonate & Weanling & Neonate & Weanling \\
\hline $\begin{array}{l}\mathrm{B}_{\max } \\
\text { (sites/cell) }\end{array}$ & $6000 \pm 266^{*}$ & $27500 \pm 8440 \dagger$ & $7750 \pm 2100$ & $8700 \pm 1500$ \\
\hline $\mathrm{k}_{\mathrm{d}}(\mathrm{pM})$ & $950 \pm 200$ & $771 \pm 190 \dagger$ & $530 \pm 180$ & $243 \pm 121$ \\
\hline
\end{tabular}

* Neonate different from weanling $p<0.05$.

$\dagger$ Antrum different from fundus. 


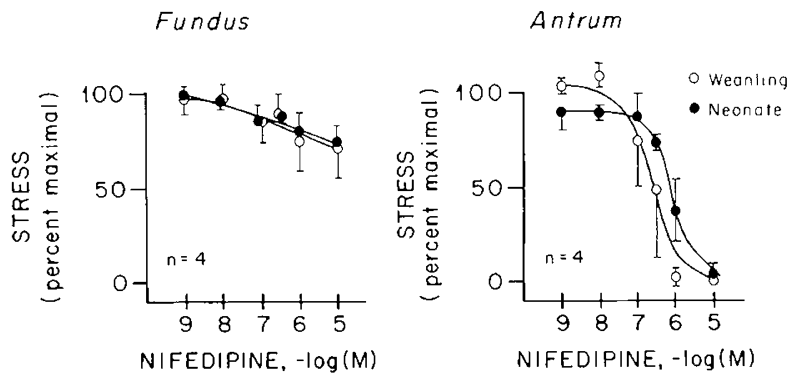

Fig. 5. Effect of nifedipine on bethanechol-stimulated contraction. Data represent the mean \pm SEM of four separate experiments.
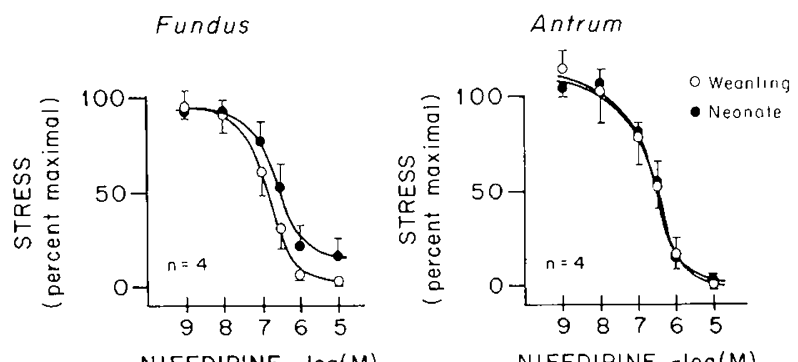

Fig. 6. Effect of nifedipine on contraction stimulated by high extracellular potassium concentration. Data represent the mean \pm SEM of four separate experiments.

and then incubated in $\mathrm{Ca}^{+2}$ free buffer $\left(0 \mathrm{Ca}^{+2}, 5\right.$-mM EGTA) there was complete inhibition of both bethanechol- and $\mathrm{K}^{+}$stimulated contraction at both ages. Contractions in response to these stimulants returned when the calcium free buffer was replaced with buffer containing calcium.

As shown in Figure 5, nifedipine $10 \mu \mathrm{M}$ inhibited $100 \%$ of bethanechol stimulated contraction in the antrum but only $25 \%$ in the fundus at both ages. In contrast, nifedipine $10 \mu \mathrm{M}$ completely inhibited contraction stimulated by increased extracellular $\mathrm{K}^{+}$concentration in both fundus and antrum at both ages (Fig. 6).

\section{DISCUSSION}

In isolated smooth muscle cells from the fundus and antrum of rabbit stomach $\left[{ }^{3} \mathrm{H}\right]$ nitrendipine binding was rapid, saturable, reversible and linearly proportional to tissue concentration. $\mathrm{Ni}$ trendipine inhibited isometric tension generated by bethanechol and potassium in concentration-dependent fashion in antral muscle strips. These results satisfy the generally accepted criteria for specific receptor binding. There were two advantages to using isolated cells rather than tissue homogenates or membranes for binding studies. First, it was possible to measure directly the number of $\left[{ }^{3} \mathrm{H}\right]$ nitrendipine binding sites/cell. Second, we avoided $\left[{ }^{3} \mathrm{H}\right]$ nitrendipine binding to intracellular receptors exposed by disruption of the cells (12).

Although the ratio of specific to nonspecific binding was relatively low, these results were consistent with earlier studies of colonic myocytes (13), and homogenates of ileal muscle (14). In our laboratory colonic myocytes have double the number of receptors/cell as the adult gastric antral myocytes, and so have nearly double the specific binding; by contrast, nonspecific binding to the filters remained constant (13).

There is a direct relationship between intracellular $\mathrm{Ca}^{+2}$ concentration and the force developed by smooth muscle (15). There is also a relationship among the number of calcium channels, the percentage of time that they are open, and the intracellular calcium concentration (16). This relationship is not exactly linear, but all calcium channels do not open until the membrane is depolarized more positive to $+100 \mathrm{mV}$. The maximum contraction of the muscle occurs at approximately $\mathrm{pCa}^{+2} 6.5$. Therefore, although increases in contraction of adult compared to neonatal tissues may be due to increased myocyte size (17), maturation of contractile proteins or other unknown factors, increasing numbers of calcium channels may be necessary to promote a rapid and equal diffusion of $\mathrm{Ca}^{+2}$ throughout the cytoplasm. Unlike many receptors for agonist-mediated events, there is no evidence for "spare" calcium channels. The control of $\mathrm{Ca}^{+2}$ influx is due to the activation and inactivation of the channels. Calcium channels inactivate as the intracellular calcium concentration increases (18).

In the present study there was an age-related increase in the number of nitrendipine-sensitive calcium channels in antral but not fundic cells. This divergence in the number of nitrendipine binding sites during maturation of the two gastric muscle tissues is consistent with their different means of increasing intracellular calcium for stimulus-contraction coupling. Previous studies in cats established that fundic smooth muscle utilized calcium stored in intracellular sites during contraction, but antral myocytes were dependent on an extracellular supply of calcium (6).

In the present study there were age-related changes in the maximal stress generated by muscle strips as measured by isometric techniques. In the antrum the combination of age-related increases in maximal stress and in the number of calcium channels was consistent with the association between stress and requirement for extracellular $\mathrm{Ca}^{+2}$ influx (15). Age-related increases in the number of calcium channels may increase $\mathrm{Ca}^{+2}$ influx and thus support the stress generated by developing antral muscle.

In the antrum the calcium channel blocker nifedipine inhibited both voltage-dependent potassium-stimulated, and receptor-operated bethanechol-stimulated contraction, observations consistent with a requirement for extracellular $\mathrm{Ca}^{+2}$ influx for contraction. In contrast, in the fundus receptor-operated bethanecholstimulated contraction was inhibited only $25 \%$ by maximally effective concentrations of the calcium channel blocker nifedipine. These observations were consistent with the absence of a requirement for extracellular $\mathrm{Ca}^{+2}$ influx for agonist-stimulated contraction in the fundus.

In summary, in the fundus, which used intracellular sources for the calcium required for contraction, calcium channels did not increase with age. In the antrum, which used extracellular $\mathrm{Ca}^{+2}$ for contraction, dihydropyridine-sensitive calcium channels increase in number with postnatal age.

\section{REFERENCES}

1. Tomomasa T, Hyman PE, Hsu CT, Jing J, Snape WJ Jr 1988 Developmen of the muscarinic receptor in rabbit gastric smooth muscle. Am J Physiol 254:G680 G686

2. Tomomasa T, Itoh Z, Koizumi T, Kurome T 1988 Non-migrating rhythmic activity in the stomach and duodenum of neonates. Biol Neonate 48:1-9

3. Park S, Rasmussen H 1985 Activation of tracheal smooth muscle contraction; synergism between $\mathrm{Ca}^{2+}$ and activators of protein kinase C. Proc Natl Acad Sci USA 82:8835-8839

4. Biancani P, Hillemeier C, Bitar KN, Makhlouf GM 1987 Contraction mediated by $\mathrm{Ca}^{2+}$ influx in esophageal muscle and by $\mathrm{Ca}^{2+}$ release in the LES. Am J Physiol 253:G760-G766

5. Meyer JH 1987 Motility of the stomach and gastroduodenal junction, In: Johnson LR (ed) Physiology of the Gastrointestinal Tract. Raven Press, New York, pp 613-629

6. Hillemeier C, Behar J, Biancani P 1986 Role of calcium in contraction of smooth muscle in the upper gastrointestinal tract of the cat. Gastroenterology 90:1459(abstr)

7. Flockerzi V, Oeken H, Hoffmann F, Pelzer D, Cavalie A, Trautwein W 1986 Purified dihydropyridine-binding site from skeletal muscle t-tubules is a functional calcium channel. Nature 323:66-68

8. Bitar KN, Makhlouf GM 1982 Receptors on smooth muscle cells: characterization by contraction and specific antagonists. Am J Physiol 242:G400G407

9. Collins SM, Gardner JD 1982 Cholecystokinin-induced contraction of dispersed smooth muscle cells. Am J Physiol 243:G497-G504

10. Tucker HS, Snape WJ Jr, Cohen S 1978 Comparison of proximal and distal 
colonic muscle of the rabbit. Am J Physiol 237:E383-E388

11. McPherson GA EBDA. 1985 Elseview-Biosoft, Cambridge, UK, pp 14-97

12. Grover AK, Kwan C, Luchowski E, Daniel EE, Triggle DJ 1984 Subcellular distribution of $\left[{ }^{3} \mathrm{H}\right]$ nitrendipine binding in smooth muscle. J Biol Chem 259:2223-2226

13. Hyman PE. Hsu ("T, Jing J, Tomomasa T, Kao HW, Snape WJ Jr $198 /$ ['H] Nitrendipine binding to rabbit colonic smooth muscle. Gastroenterology 92:1441(abstr)

14. Bolger GT, Gengo P, Klockouski R, Luchowski E, Sicgal H, Janis RA, Triggle AM. Triggle DJ 1983 Characterization of binding of the $\mathrm{Ca}^{2+}$ channel antagonist $\left[{ }^{3} \mathrm{H}\right]$ nitrendipine to guinea-pig ileal smooth muscle. J Pharmacol
Exp Ther 225:291-309

15. Sevy NJ, Snape WJ Jr 1988 Sources of calcium for contraction of distal circular muscle or taenia coli in the rabbit. Am J Physiol 254:G808-G813

16. Hille, B 1984 Ionic Channels of Excitable Membranes. Sinauer Associates, Inc., Sunderland, MA, pp 76-98

17. Gabella G 1987 Dynamic aspects of the morphology of the intestinal muscle coat. In: Szurszewski JH (ed). Cellular Physiology and Clinical Studies of Gastrointestinal Smooth Muscle. Elsevier Science Publishers, Amsterdam, pp 5-31

18. Lux HD, Brown AM 1984 Single channel studies on inactivation of calcium currents. Science 225:432-434 